\title{
Terms and Abbreviations
}

BASIC LAW The Grundgesetz was West Germany's constitution.

BUNDESTAG The lower and more powerful house of the West German parliament.

CDU

The Christian Democratic Union (Christlich Demokratische Union Deutschlands) is postwar Germany's principal centre-right political party. It occupied the West German Chancellorship during 1949-69 and 1982-90.

CSU The Christian Social Union (Christlich-Soziale Union in Bayern) is the CDU's sister party in Bavaria, the southern federal state where the CDU does not contest elections.

FDJ The Free German Youth (Freie Deutsche Jugend) was East Germany's official youth organization.

FDP The Free Democratic Party (Freie Demokratische Partei) is Germany's classically liberal party, advocating personal liberty and free markets. For most of West Germany's existence, it governed as the junior coalition partner with either the CDU/CSU or the SPD.

FRG The Federal Republic of Germany (Bundesrepublik Deutschland), also known as WEST GERMANY.

GDR The German Democratic Republic (Deutsche Demokratische Republik), also known as EAST GERMANY.

IM An unofficial collaborator (inoffizieller Mitarbeiter) was an informant, often an ordinary citizen, recruited by the Stasi to pass information to the secret police.

KPD The Communist Party of Germany (Kommunistische Partei Deutschlands). The party was a major political force in the Weimar Republic. It ceased to exist in what became the GDR in 1946 after it merged with the SPD to form the SED. The West German government banned it in 1956. 
MÄNNERBUND

MFS

NATO

NVA

REICHSTAG

REPUBLIKFLUCHT

SED

SEW

SPD

VERFASSUNGSSCHUTZ

VOLKSKAMMER
Homosocial associations of men, which can be translated as male association, society, or covenant. It is a cornerstone of the masculinist conceptualization of malemale desire.

The Ministry for State Security (Ministerium für Staatssicherheit), better known as the STASI. The MfS was East Germany's secret police and intelligence service.

The North Atlantic Treaty Organization, founded in 1949 to cement the alliance among the United States and Western European countries. West Germany was admitted to the alliance in 1955.

The National People's Army (Nationale Volksarmee) was East Germany's military.

The lower house of the German parliament between 1871 and 1945 .

Literally "flight from the republic," Republikflucht denoted the crime of illegally leaving the GDR.

The Socialist Unity Party (Sozialistische Einheitspartei) was East Germany's ruling party from 1949 until 1990. It was the product of a forced merger of the East German KPD and SPD in 1946. Although it technically ruled the GDR in coalition with other parties, including the CDU, it was guaranteed the leadership of the state in the 1968 East German constitution.

The Socialist Unity Party of West Berlin (Sozialistische Einheitspartei Westberlins) was the SED's sister party in West Berlin.

The Social Democratic Party of Germany (Sozialdemokratische Partei Deutschlands) is Germany's principal centre-left party and the oldest extant party in Germany. It governed West Germany from 1969 to 1982 in coalition with the FDP.

West Germany's domestic counter-intelligence agency. It translates literally as "constitution protection."

The East German parliament. 